\title{
Evaluation of Pollution Sources of Zinc in Tokyo Bay Based on Zinc Isotope Ratio in Sediment Core
}

\author{
Masahiro Sakata1 $^{*}$, Shohei Okuizumi1 ${ }^{1}$, Asami Suzuki Mashio², Takeshi Ohno ${ }^{3}$, Shuhei Sakata ${ }^{3}$ \\ ${ }^{1}$ Graduate Program in Environmental Health Sciences, University of Shizuoka, Shizuoka, Japan \\ ${ }^{2}$ Graduate School of Natural Science and Technology, Kanazawa University, Kanazawa, Japan \\ ${ }^{3}$ Department of Chemistry, Faculty of Science, Gakushuin University, Tokyo, Japan \\ Email: *sakatam@u-shizuoka-ken.ac.jp
}

How to cite this paper: Sakata, M., Okuizumi, S., Mashio, A. S., Ohno, T., \& Sakata, S. (2019). Evaluation of Pollution Sources of Zinc in Tokyo Bay Based on Zinc Isotope Ratio in Sediment Core. Journal of Geoscience and Environment Protection, 7, 141-154.

https://doi.org/10.4236/gep.2019.78010

Received: July 14, 2019

Accepted: August 16, 2019

Published: August 19, 2019

Copyright $\odot 2019$ by author(s) and Scientific Research Publishing Inc. This work is licensed under the Creative Commons Attribution International License (CC BY 4.0).

http://creativecommons.org/licenses/by/4.0/

\begin{abstract}
This study evaluated the sources of Zn pollution in Tokyo Bay, Japan, on the basis of $\delta^{66} \mathrm{Zn}$ in a sediment core. The $\mathrm{Zn}$ concentration in sediments in the 1980s-2000s was considerably higher than the background concentration, suggesting that there remain important sources of $\mathrm{Zn}$ in the bay. The $\delta^{66} \mathrm{Zn}$ $(+0.51 \%)$ of anthropogenic $\mathrm{Zn}$ estimated in the core was significantly higher than those (approximately $-0.1 \% 0-+0.2 \%$ ) of treated water from sewage treatment plants and vehicle-related sources. A large number of electroplating plants are located in Tokyo areas. It is assumed that $\mathrm{Zn}$ in effluents from electroplating operations is isotopically heavier owing to a negative isotopic effect on $\mathrm{Zn}$ electroplating. This tends to support the hypothesis that river bottom sediments, which were contaminated with $\mathrm{Zn}$ in the untreated effluents from electroplating plants in the past, are the principal sources of anthropogenic $\mathrm{Zn}$ in Tokyo Bay in the 1980s-2000s.
\end{abstract}

\section{Keywords}

Zinc, Pollution Sources, Sediment Core, Zinc Isotope Ratio, Tokyo Bay

\section{Introduction}

Aquatic regions, which are particularly surrounded by populated and industrialized areas, easily accumulate toxic trace substances, including heavy metals, organochlorine compounds (e.g., PCBs and dioxins), and other compounds of anthropogenic origin. Diagenetic remobilization of sulfide-forming metals, including $\mathrm{Cd}, \mathrm{Cu}, \mathrm{Hg}, \mathrm{Pb}$, and $\mathrm{Zn}$, in sediments is considered negligible owing to 
their fixation as sulfides under anoxic conditions (Kitano et al., 1980; Sakata, 1985; Canavan et al., 2007). Hence, the history of pollution by these metals has frequently been recorded in sediment cores from closed aquatic regions such as bays and lakes. In developed countries, a downward historical trend of their pollution has been generally observed in the cores owing to pollution control in industries and utilities (e.g., Hirao et al., 1986; Pearson et al., 1997; Fox et al., 1999; Hornberger et al., 1999; Yasuhara \& Yamazaki, 2005; Heim et al., 2004; Mahler et al., 2006; Sakata et al., 2008; Hosono et al., 2010). Among heavy metals, however, zinc $(\mathrm{Zn})$ concentration in sediments in recent years is significantly higher than the background concentration (Mahler et al., 2006; Sakata et al., 2008; Thapalia et al., 2010, 2015). Thus, $\mathrm{Zn}$ is still an important pollutant in aquatic environments even in developed countries, suggesting that there remain major sources of $\mathrm{Zn}$. Clarifying the sources in aquatic environments is essential for achieving the effective reduction of the environmental risks associated with $\mathrm{Zn}$ and also the conservation of ecosystems (Tang et al., 2014).

$\mathrm{Zn}$ originates from various point and nonpoint sources, including waste-burning, power generation, refining, and the manufacturing and disposal of products such as galvanized steel, rubber, cement, fertilizer, medicines, and cosmetics (Thapalia et al., 2015). Particularly in urban environments, stormwater runoff has been also recognized as a major nonpoint source owing to an increase in flow that mobilizes various pollutants (e.g., atmospheric deposition, vehicle exhausts and tires, and road debris) deposited on the land surface and river bottom (e.g., Characklis \& Wiesner, 1997; Sansalone \& Buchberger, 1997; Brown \& Peake, 2005; Westerlund \& Viklander, 2006; Eckley \& Branfireum, 2008; Kang et al., 2009; Sakata et al., 2010).

Zinc isotope ratio, such as ${ }^{66} \mathrm{Zn} /{ }^{64} \mathrm{Zn}$ (expressed as $\delta^{66} \mathrm{Zn}$ ), may provide useful information on the sources of $\mathrm{Zn}$ in environmental samples when each source of $\mathrm{Zn}$ has a distinctive isotope ratio. Thapalia et al. (2010) measured $\delta^{66} \mathrm{Zn}$ to identify the sources of $\mathrm{Zn}$ in a sediment core from Lake Ballinger near Seattle, USA. The upward historical trend of $\mathrm{Zn}$ concentration and conversely the downward historical trend of $\delta^{66} \mathrm{Zn}$ were observed in the core since approximately 1900. These trends reflect the effects of atmospheric emissions from a nearby smelter and rapid urbanization of the watershed. Urban sources of $\mathrm{Zn}$ were dominant since the smelter closed in the $1980 \mathrm{~s}$, and the $\delta^{66} \mathrm{Zn}$ measured in tire samples suggested that tire wear is a likely source of $\mathrm{Zn}$. Moreover, Thapalia et al. (2015) measured $\mathrm{Zn}$ concentration and $\delta^{66} \mathrm{Zn}$ in sediment cores collected from eight lakes and reservoirs across the US. The relationship between $\mathrm{Zn}$ concentration and $\delta^{66} \mathrm{Zn}$ indicated that the lakes and reservoirs with greater than $70 \%$ urban land use in the watershed are affected by large amounts of $\mathrm{Zn}$ from primarily vehicle-related sources such as tire wear and emissions. On the other hand, Chen et al. (2008) reported that dissolved $\mathrm{Zn}$ in the Seine River, France, is essentially of anthropogenic origin $(>90 \%)$ rather than natural sources $(<7 \%)$, and that roof leaching from Paris conurbations is a major source of $\mathrm{Zn}$. The above-mentioned 
anthropogenic sources of $\mathrm{Zn}$ are characterized by $\delta^{66} \mathrm{Zn}$ values of $+0.05 \%$ o $0.10 \%$ o lower than those $(+0.35 \%$ o $0.43 \%$ o $)$ of the natural sources (Chen et al., 2008; Thapalia et al., 2015). However, whether this is common in aquatic regions polluted by $\mathrm{Zn}$ remains to be clarified, because there are few data.

In this study, we evaluated the pollution sources of $\mathrm{Zn}$ in Tokyo Bay (Figure 1 ), Japan, on the basis of $\delta^{66} \mathrm{Zn}$ in a sediment core. It should be noted that the historical trend of pollution sources of $\mathrm{Pb}$ in Tokyo Bay was already investigated on the basis of $\mathrm{Pb}$ isotope ratios in the same core (Sakata et al., 2018). Tokyo Bay has an area of $960 \mathrm{~km}^{2}$ and a mean depth of $15 \mathrm{~m}$. The bay is surrounded by a densely populated (approximately 26 million) and highly industrialized area. Many anthropogenic sources, including steel mills, petrochemical plants, and municipal solid waste incinerators, are located in its coastal regions. Sakata et al. (2008) reported the historical trend of pollution by $\mathrm{As}, \mathrm{Cd}, \mathrm{Cr}, \mathrm{Cu}, \mathrm{Hg}$, and $\mathrm{Pb}$ recorded in a sediment core dated with ${ }^{210} \mathrm{~Pb}$. The results showed that the pollution levels in Tokyo Bay increased abruptly after about 1950, reaching their maximum in the early 1970s, during which time, pollution control in industries and utilities started in earnest. For some metals such as $\mathrm{Zn}$ and $\mathrm{Cd}$, however, their pollution levels in sediments after the 1980s were significantly higher than the background levels (unpublished data from the same authors for $\mathrm{Zn}$ ). Moreover, Sakata et al. (2008) indicated that the contribution of atmospheric deposition of $\mathrm{As}, \mathrm{Cd}, \mathrm{Cr}, \mathrm{Cu}, \mathrm{Hg}$, and $\mathrm{Pb}$ to the bay ranges from $5 \%$ to $26 \%$ on the basis of a mass balance study, suggesting the importance of river and effluent discharges as the sources of their metals. Unfortunately, there is no data on the mass balance of $\mathrm{Zn}$ in Tokyo Bay due to the contamination of samples by $\mathrm{Zn}$. However, we believe that the contribution of the atmospheric deposition of $\mathrm{Zn}$ to the bay is significantly smaller than those of river and effluent discharges on the basis of a mass balance study of other heavy metals. This is likely supported by the finding that the $\mathrm{Zn}$ concentration decreases rapidly with increasing distance from the mouth of principal rivers flowing into the bay (Terashima et al., 2007). To obtain data from river and effluent discharges, we measured $\mathrm{Zn}$ concentration and $\delta^{66} \mathrm{Zn}$ in water samples from three principal rivers, namely, Edogawa, Arakawa, and Tama and treated water samples from sewage treatment plants located along the Tama River (Figure 1).

\section{Materials and Methods}

\subsection{Sampling}

A sediment core was collected by a diver by inserting an acrylic plastic tube with a diameter of $20 \mathrm{~cm}$ and a length of $100 \mathrm{~cm}$ into the sediment at a site in Tokyo Bay (N35 34.06', E13954.32', Figure 1) in December 2003 (Sakata et al., 2006). The core was immediately cut vertically into 2 -cm-thick sections for chemical analyses. The sediment samples were dried at $80^{\circ} \mathrm{C}$ in an oven and then ground. The age of the sediment core was determined by Sakata et al. (2006) by the ${ }^{210} \mathrm{~Pb}$ dating method. 


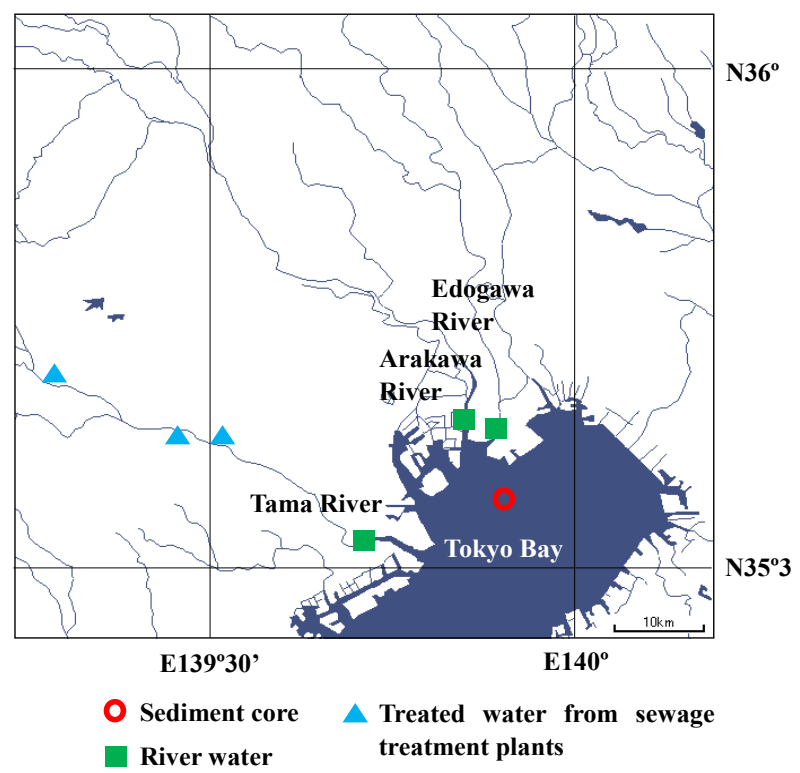

Figure 1. Location of sampling sites for sediment core, river water, and treated water from sewage treatment plants.

River water samples were collected from the three principal rivers using a Teflon sampler on bridges near estuaries (Figure 1). This sampler is entirely made of Teflon, which makes it possible to prevent the contamination and adsorption of $\mathrm{Zn}$ in the samples. In general, sampling was conducted every month from January 2004 to March 2005 during ordinary runoff and low tide on the same date of each month. In contrast, treated water samples from sewage treatment plants were collected in July 2016 from an outfall of the three plants located along Tama River (Figure 1). To the water samples, $\mathrm{HNO}_{3}(0.13-0.26$ mol. $\left.\mathrm{L}^{-1}\right)$ was added to dissolve the bulk of $\mathrm{Zn}$ associated with suspended particles.

\subsection{Chemical Analyses}

\subsubsection{Sediment Samples}

For the determination of the $\mathrm{Zn}$ concentration in sediment samples (a total of 26), $0.25 \mathrm{~g}$ of a dry sample was digested using $\mathrm{HF}-\mathrm{HNO}_{3}-\mathrm{HClO}_{4}$. After evaporation to dryness, the residue was dissolved in $10 \mathrm{~mL}$ of $0.1 \mathrm{~mol} \cdot \mathrm{L}^{-1} \mathrm{HNO}_{3}$. The $\mathrm{Zn}$ concentration in this solution was measured by inductively coupled plasma atomic emission spectrometry (ICP-AES; Varian 730ES).

The $\delta^{66} \mathrm{Zn}$ values in sediment samples (a total of 10 selected) were measured by multiple collector ICP mass spectrometry (MC-ICP-MS; Nu Plasma 500, Nu Instrument) using the above sample solution in which $\mathrm{Zn}$ isotopes were purified in advance by a column chromatography technique (Borrok et al., 2007) as follows. The column was loaded with approximately $0.5 \mathrm{~mL}$ (length, $\sim 20 \mathrm{~mm}$; diameter, $\sim 6 \mathrm{~mm}$ ) of 100 - 200 mesh AG MP-1 anion-exchange resin (Bio-Rad'). The resin was then sufficiently rinsed using $2 \mathrm{~mol} \cdot \mathrm{L}^{-1} \mathrm{HCl}$ and Milli-Q water and conditioned using $1 \mathrm{~mol} \cdot \mathrm{L}^{-1} \mathrm{HCl}$. The sample solution $\left(0.1 \mathrm{~mol} \cdot \mathrm{L}^{-1} \mathrm{HNO}_{3}\right)$ ob- 
tained from sediment digestion was evaporated to dryness, and the resulting residue was dissolved in $1 \mathrm{~mol} \cdot \mathrm{L}^{-1} \mathrm{HCl}$. This solution was loaded onto the resin bed. The required volume of sample evaporated was calculated on the basis of the initial $\mathrm{Zn}$ concentration in a sample to obtain a $\mathrm{Zn}$ concentration of 100 $\mu \mathrm{g} \cdot \mathrm{L}^{-1}$ which enables isotope analysis with good precision (described later). $\mathrm{Zn}$ was eluted by loading $6 \mathrm{~mL}$ of Milli-Q water after $4 \mathrm{~mL}$ of $1 \mathrm{~mol} \cdot \mathrm{L}^{-1} \mathrm{HCl}$ was passed through the column. This separation process was repeated three times to minimize the effects of impurities on $\mathrm{Zn}$ isotope analysis. The recovery rate of $\mathrm{Zn}$ through the separation process was higher than 95\%. Moreover, the total $\mathrm{Zn}$ blank level from the separation process was less than $30 \mathrm{ng}$, the contribution of which to the samples was less than $3 \%$. Hence, no correction for blank contribution was made in this study.

All the samples $\left(1 \% \mathrm{HNO}_{3}\right.$ solution) were prepared to obtain a $\mathrm{Zn}$ concentration of $100 \mu \mathrm{g} \cdot \mathrm{L}^{-1}$ for isotope analysis and spiked with $100 \mu \mathrm{g} \cdot \mathrm{L}^{-1} \mathrm{Cu}\left({ }^{65} \mathrm{Cu} /{ }^{63} \mathrm{Cu}=\right.$ 0.4456; NIST SRM 976) to correct the mass discrimination effect by an external correction technique using $\mathrm{Cu}$ (Ohno et al., 2005). A correction of ${ }^{64} \mathrm{Ni}$ concentration is required to eliminate spectral interference overlapping with ${ }^{64} \mathrm{Zn}$. This correction was carried out by monitoring the abundance of ${ }^{62} \mathrm{Ni}$, assuming natural isotopic abundances. There was a difference of $-0.043 \%$ o $+0.011 \%$ o between the original and corrected $\delta^{66} \mathrm{Zn}$ values of the samples after the correction of ${ }^{64} \mathrm{Ni}$ concentration. The $\mathrm{Zn}$ isotope ratio of the solution of a reference material IRMM-3702, whose $\mathrm{Zn}$ concentration was adjusted to be the same as that of a sample (i.e., $100 \mu \mathrm{g} \cdot \mathrm{L}^{-1}$ ), was measured before and after the isotope ratio measurement of the sample. The $\mathrm{Zn}$ isotope ratio of the sample was normalized to the mean isotope ratio of IRMM-3702. The mean reproducibility $(2 \sigma)$ of $\delta^{66} \mathrm{Zn}$ in all the samples was $0.07 \%$. A mass dependence plot of $\delta^{68} \mathrm{Zn}$ versus $\delta^{66} \mathrm{Zn}$ showed that there is a relation of $\delta^{68} \mathrm{Zn}=2.0 \delta^{66} \mathrm{Zn}+0.12\left(r^{2}=0.92, p<0.001\right)$. This demonstrates that spectral interferences are not present for these masses. Finally, $\delta^{66} \mathrm{Zn}$ was recalculated with respect to the isotope ratio of a reference material JMC Lyon, which is commonly used, but no longer available, on the basis of the calibration of the IRMM-3702 against the JMC Lyon ( $\delta^{66} \mathrm{Zn}_{\text {JMC Lyon }}=$ $\delta^{66} \mathrm{Zn}_{\text {IRMM-3702 }}+0.29 \%$; Moeller et al., 2012).

\subsubsection{Water Samples}

The acidified samples from rivers (15 samples collected every month for each river) and sewage treatment plants (3 samples) were passed through a $0.45 \mu \mathrm{m}$ membrane filter to remove particles. Similarly to the case of sediment samples, the $\mathrm{Zn}$ concentration and $\delta^{66} \mathrm{Zn}$ in these samples were measured by ICP-AES and MC-ICP-MS, respectively. For the determination of $\delta^{66} \mathrm{Zn}$ in the river water samples, one sample collected in each season (4 samples) was selected for each river. Moreover, the $\mathrm{Al}$ concentration in the filtrated samples was measured by ICP-AES to use as an indicator of lithogenic particles originating from soil or river bottom sediments. 


\section{Results}

\subsection{Vertical Profiles of $\mathrm{Zn}$ Concentration and $\delta^{66} \mathrm{Zn}$ in Sediment Core}

The $\mathrm{Zn}$ concentration in the sediment core is plotted as a function of time based on ${ }^{210} \mathrm{~Pb}$ dating in Figure 2. The $\mathrm{Zn}$ consumption from 1950 to 2000 in Japan (https://www.aist-riss.jp/wp-content/uploads/2014/10/Zn_Summary.pdf) is also given in the figure. The background concentration of $\mathrm{Zn}$ in Tokyo Bay sediments is approximately $80 \mu \mathrm{g} \cdot \mathrm{g}^{-1}$ (Kitano et al., 1980), showing that Zn pollution in Tokyo Bay started before 1880. The $\mathrm{Zn}$ concentration increased abruptly after about 1950, and then decreased from the late 1970s to the 1980s. On the other hand, the Zn consumption in Japan increased abruptly from about 1950 to the mid-1970s, and tended to decrease gradually from about 1990. It is likely that the enhanced release of $\mathrm{Zn}$ into the water environment associated with the $\mathrm{Zn}$ consumption worsened the $\mathrm{Zn}$ pollution from about 1950 to the mid-1970s in Tokyo Bay. After that time, the $\mathrm{Zn}$ concentration in the core decreased, but that $\left(400 \mu \mathrm{g} \cdot \mathrm{g}^{-1}\right)$ in the surface layer (2001-2003) of the core is still sufficiently high, which is similar to the concentration in the 1960s. Thus, the $\mathrm{Zn}$ pollution in Tokyo Bay is in progress at a higher level even after the 1980s, during which time, pollution control in industries and utilities was being established. This implies that important anthropogenic sources contribute to the $\mathrm{Zn}$ pollution in Tokyo Bay.

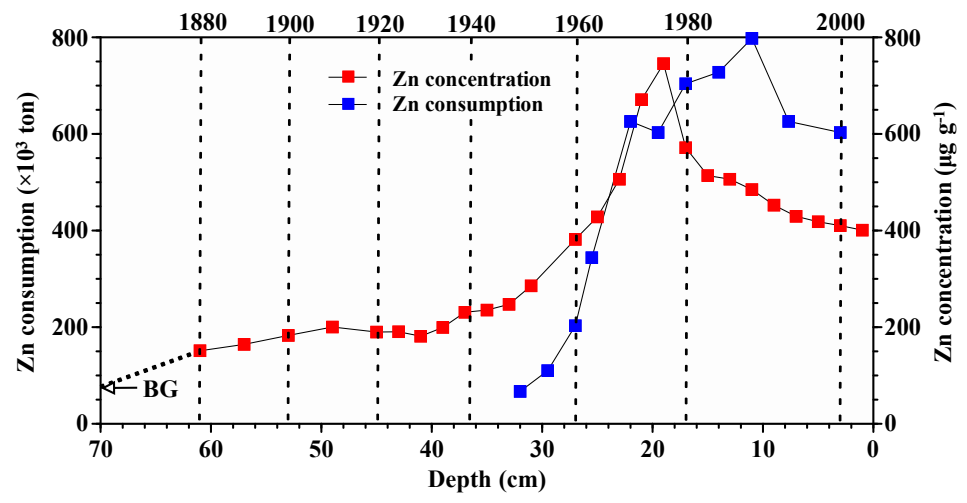

Figure 2. Vertical profile of $\mathrm{Zn}$ concentration in sediment core as a function of time. The $\mathrm{Zn}$ consumption from 1950 to 2000 in Japan (https://www.aist-riss.jp/wp-content/uploads/ 2014/10/Zn_Summary.pdf) is also given in the figure.

Figure 3 shows the vertical profile of $\delta^{66} \mathrm{Zn}$ (mean $\pm 2 \sigma$ ) in the sediment core as a function of time. There was no marked change in the $\delta^{66} \mathrm{Zn}$ in the core in 1900-1940. After this period, however, $\delta^{66} \mathrm{Zn}$ increased gradually and reached a maximum around 1970, and then $\delta^{66} \mathrm{Zn}$ decreased from the late 1970 s to the $1980 \mathrm{~s}$. Thus, the vertical profile of $\delta^{66} \mathrm{Zn}$ in the core is similar to that of $\mathrm{Zn}$ concentration. This suggests that anthropogenic sources, which brought about the rapid increase in $\mathrm{Zn}$ concentration since about 1950, are characterized by high $\delta^{66} \mathrm{Zn}$ values. 


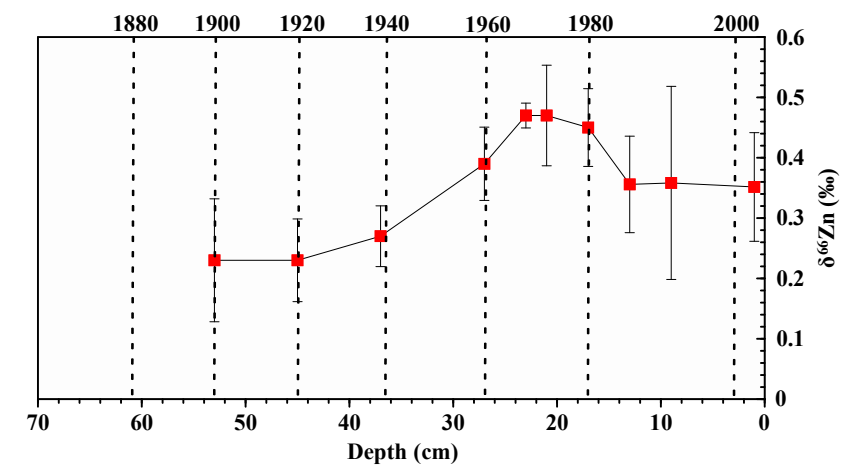

Figure 3. Vertical profile of $\delta^{66} \mathrm{Zn}$ (mean $\pm 2 \sigma$ ) in sediment core as a function of time.

\section{2. $\mathrm{Zn}$ Concentration and $\delta^{66} \mathrm{Zn}$ in River Water and Treated Water from Sewage Treatment Plants}

The $\mathrm{Zn}$ concentrations (mean $\pm 1 \sigma$ ) in water samples from three principal rivers were $22 \pm 15 \mu \mathrm{g} \cdot \mathrm{L}^{-1}$ for Edogawa River, $18 \pm 8 \mu \mathrm{g} \cdot \mathrm{L}^{-1}$ for Arakawa River, and 13 $\pm 4 \mu \mathrm{g} \cdot \mathrm{L}^{-1}$ for Tama River. In contrast, the $\mathrm{Zn}$ concentration (mean $\pm 1 \sigma$ ) in the treated water samples from sewage treatment plants located along the Tama River was $37 \pm 10 \mu \mathrm{g} \cdot \mathrm{L}^{-1}$. Thus, the $\mathrm{Zn}$ concentration in the treated water from sewage treatment plants was higher than those in the river water, suggesting that the treated water from sewage treatment plants contributes to $\mathrm{Zn}$ pollution in the rivers. Figure 4 shows that there is a significant correlation $\left(r^{2}=0.71, p<\right.$ 0.001 ) between the concentrations of $\mathrm{Zn}$ and $\mathrm{Al}$ in the three rivers. Hence, it is likely that the $\mathrm{Zn}$ concentration in the rivers increases with increasing amount of lithogenic particles. This suggests that $\mathrm{Zn}$ is transported through rivers primarily in particulate form associated with soil or river bottom sediments. Moreover, Figure 4 indicates that particles in the rivers are highly polluted by $\mathrm{Zn}$, because the $\mathrm{Zn} / \mathrm{Al}$ concentration ratio in the rivers is markedly higher than that in the upper crust of Japan (Zn, 74.1 $\mu \mathrm{g} \cdot \mathrm{g}^{-1}$; Al, 77,600 $\mu \mathrm{g} \cdot \mathrm{g}^{-1}$; Togashi et al., 2000).

The relationship between $\mathrm{Zn}$ concentration and $\delta^{66} \mathrm{Zn}$ in the rivers is shown in Figure 5, which indicates that $\delta^{66} \mathrm{Zn}$ increases with increasing $\mathrm{Zn}$ concentration in the rivers $\left(r^{2}=0.59, p<0.01\right)$. As mentioned earlier, it is probable that the $\mathrm{Zn}$ concentration in the rivers increases with increasing amount of lithogenic particles. This implies that $\mathrm{Zn}$ associated with soil or river bottom sediments has a relatively high $\delta^{66} \mathrm{Zn}$ (probably $>+0.4 \%$ ). On the other hand, the $\delta^{66} \mathrm{Zn}$ values in the treated water from sewage treatment plants were relatively low, ranging from $+0.05 \%$ o to $+0.11 \%$ o (mean $\pm 2 \sigma, 0.08 \%$ o $\pm 0.06 \%$ ) , which were close to the values $(-0.03 \%$ - $+0.08 \%$ ) reported for the plant-treated wastewaters in the Paris area (Chen et al., 2008). It appears that $\mathrm{Zn}$ in the rivers originates primarily from two sources, namely, soil or river bottom sediments highly polluted by $\mathrm{Zn}$

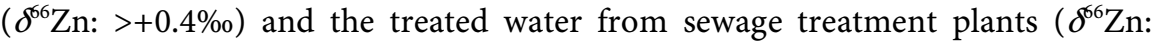
approximately $-0.2 \% 0-+0.1 \%$ ). Thus, the $\delta^{66} \mathrm{Zn}$ of the rivers may depend on the mixing of these two sources. 


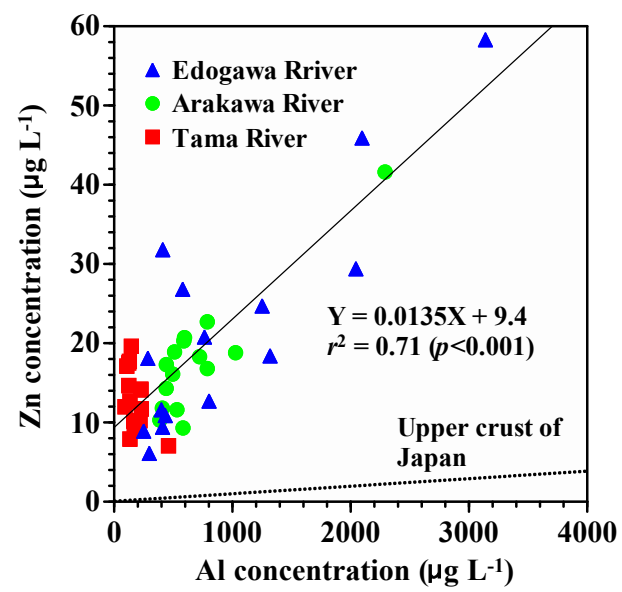

Figure 4. Relationship between concentrations of $\mathrm{Zn}$ and $\mathrm{Al}$ in three principal rivers. The figure indicates that the $\mathrm{Zn} / \mathrm{Al}$ concentration ratio in the rivers is markedly higher than that in the upper crust of Ja-

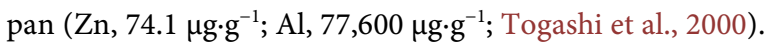

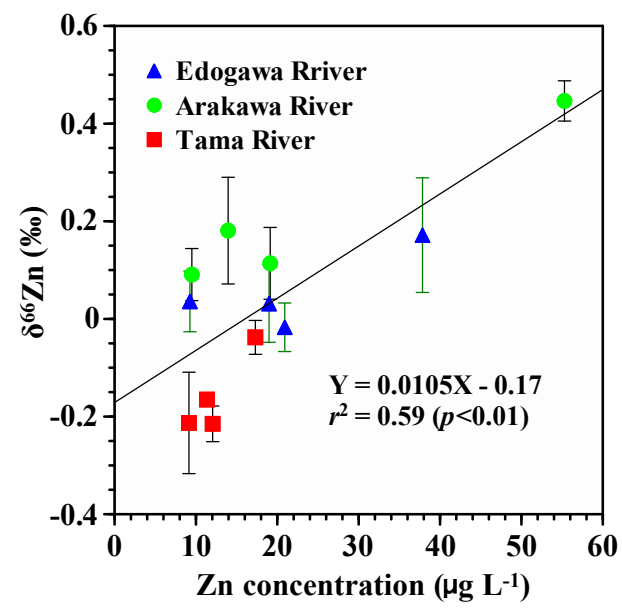

Figure 5. Relationship between $\delta^{66} \mathrm{Zn}$ (mean $\pm 2 \sigma$ ) and $\mathrm{Zn}$ concentration in three principal rivers.

As mentioned in section 2.2.2, we measured the concentration and $\delta^{66} \mathrm{Zn}$ of dissolved $\mathrm{Zn}$ plus particulate $\mathrm{Zn}$ in river water. On the basis of our previous study of the Tama River (Sakata et al., 2010), the ratio of particulate Zn was approximately $20 \%$ at the total $\mathrm{Zn}$ concentration of $10 \mu \mathrm{g} \cdot \mathrm{L}^{-1}$, and increased abruptly with increasing total $\mathrm{Zn}$ concentration. Hence, it is assumed that $\mathrm{Zn}$ in river water, which was measured in this study, exists mostly in particulate form. On the other hand, Chen et al. (2008) measured the concentration and $\delta^{66} \mathrm{Zn}$ of only dissolved $\mathrm{Zn}$ in the Seine River. The measured $\mathrm{Zn}$ concentrations ranged from approximately $20-70 \mathrm{nmol} \cdot \mathrm{L}^{-1}\left(1-5 \mu \mathrm{g} \cdot \mathrm{L}^{-1}\right)$, which corresponded to only $1 / 10$ of the concentrations measured in this study (Figure 4). Chen et al. (2008) reported that leaching from roofs in Paris conurbation is a major source of dissolved $\mathrm{Zn}$. However, there is a possibility of other sources of particulate $\mathrm{Zn}$ in the river, because this $\mathrm{Zn}$ is affected directly by soil or river bottom sediments. 


\section{Discussion}

As mentioned in section 3.1, it is probable that anthropogenic sources, which brought about the rapid increase in $\mathrm{Zn}$ concentration since about 1950, are characterized by high $\delta^{6} \mathrm{Zn}$ values. To simplify our examination, we assumed that anthropogenic $\mathrm{Zn}$ with high $\delta^{66} \mathrm{Zn}$ has been added to background $\mathrm{Zn}$ in sediments. Then, the $\delta^{66} \mathrm{Zn}$ of anthropogenic $\mathrm{Zn}$ in the sediment core was estimated using the two-component end-member equation commonly and widely utilized.

$$
\begin{gathered}
\mathrm{Zn}_{\mathrm{T}}=\mathrm{Zn}_{\mathrm{A}}+\mathrm{Zn}_{\mathrm{B}} \\
\delta^{66} \mathrm{Zn}_{\mathrm{T}}=\delta^{66} \mathrm{Zn}_{\mathrm{A}}\left(\frac{\mathrm{Zn}_{\mathrm{A}}}{\mathrm{Zn}_{\mathrm{T}}}\right)+\delta^{66} \mathrm{Zn}_{\mathrm{B}}\left(\frac{\mathrm{Zn}_{\mathrm{B}}}{\mathrm{Zn}_{\mathrm{T}}}\right)
\end{gathered}
$$

where $\mathrm{Zn}_{\mathrm{T}}, \mathrm{Zn}_{\mathrm{A}}$, and $\mathrm{Zn}_{\mathrm{B}}$ are the concentrations of total $\mathrm{Zn}$, anthropogenic $\mathrm{Zn}$, and background $\mathrm{Zn}$ in sediments, respectively. Similarly, $\delta^{66} \mathrm{Zn}_{\mathrm{T}}, \delta^{66} \mathrm{Zn}_{\mathrm{A}}$, and $\delta^{66} \mathrm{Zn}_{\mathrm{B}}$ are the $\delta^{66} \mathrm{Zn}$ of total $\mathrm{Zn}$, anthropogenic $\mathrm{Zn}$, and background $\mathrm{Zn}$ in sediments, respectively. Combining Equations (1) and (2) gives Equation (3).

$$
\delta^{66} \mathrm{Zn}_{\mathrm{T}}=\frac{1}{\mathrm{Zn}_{\mathrm{T}}} \mathrm{Zn}_{\mathrm{B}}\left(\delta^{66} \mathrm{Zn}_{\mathrm{B}}-\delta^{66} \mathrm{Zn}_{\mathrm{A}}\right)+\delta^{66} \mathrm{Zn}_{\mathrm{A}}
$$

Thus, a plot of $\delta^{66} \mathrm{Zn}_{\mathrm{T}}$ versus $1 / \mathrm{Zn}_{\mathrm{T}}$ should yield a straight line with a $\mathrm{y}$-intercept of $\delta^{66} \mathrm{Zn}_{\mathrm{A}}$. This allows us to estimate $\delta^{66} \mathrm{Zn}_{\mathrm{A}}$, that is, the $\delta^{66} \mathrm{Zn}$ of anthropogenic $\mathrm{Zn}$ in the sediment core.

Figure 6 shows a plot of $\delta^{66} \mathrm{Zn}_{\mathrm{T}}$ versus $1 / \mathrm{Zn}_{\mathrm{T}}$, resulting in a straight line between the parameters $\left(r^{2}=0.82, p<0.001\right)$. The y-intercept of the line gives $+0.51 \%$ as the $\delta^{66} \mathrm{Zn}$ of anthropogenic $\mathrm{Zn}$ in the sediment core. To the best of our knowledge, such a high $\delta^{66} \mathrm{Zn}$ will be the first report for anthropogenic $\mathrm{Zn}$ in aquatic regions. This $\delta^{66} \mathrm{Zn}$ is much higher than those $(+0.05 \%$ o $-0.11 \%$ o $)$ of the treated water from sewage treatment plants measured in this study. Vehicle-related sources, such as tire wear and vehicle emissions, are the dominant sources of $\mathrm{Zn}$ in urban watersheds with high traffic (Thapalia et al., 2010, 2015). However, these sources are characterized by low $\delta^{66} \mathrm{Zn}$ values $(+0.05 \%$; Thapalia et al., 2015). In addition, Thapalia et al. (2010) reported that the $\delta^{66} \mathrm{Zn}$ of tire samples $(n=5)$ ranges from $-0.10 \%$ o to $+0.14 \%$. We also confirmed that the $\delta^{66} \mathrm{Zn}$ values of dust samples $(\mathrm{n}=3)$ collected in road tunnels in Shizuoka City, Japan are significantly lower $(-0.04 \%$ - $+0.29 \%$; unpublished data by M. Sakata). Hence, $\mathrm{Zn}$ from vehicle-related sources cannot explain the high $\delta^{66} \mathrm{Zn}$ of anthropogenic $\mathrm{Zn}$ in the sediments from Tokyo Bay.

It was described previously that the $\mathrm{Zn}$ consumption in Japan increased abruptly from 1950 to the mid-1970s, and then tended to decrease gradually from about 1990 (Figure 2). Within the total Zn consumption, the consumption related to electroplating accounted for approximately $60 \%-70 \%$ (https://www.aist-riss.jp/wp-content/uploads/2014/10/Zn_Summary.pdf). A large number of electroplating plants locates currently in the Tokyo area (312 plants; http://www.tmk.or.jp/). This makes it possible to expect that effluent discharges from electroplating plants contribute to $\mathrm{Zn}$ pollution in Tokyo Bay. 


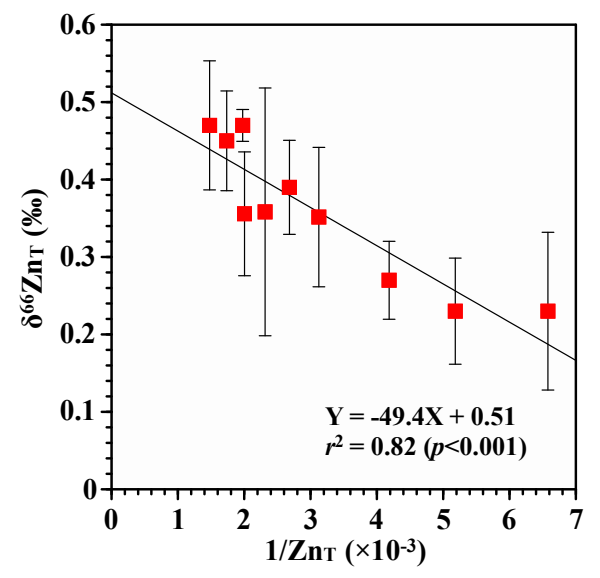

Figure 6. Plot of $\delta^{66} \mathrm{Zn}_{\mathrm{T}}($ mean $\pm 2 \sigma)$ versus $1 / \mathrm{Zn}_{\mathrm{T}}$ in sediment core.

At present, the public sewerage system is almost completely established in the Tokyo area, and effluents from electroplating plants are required to connect to the public sewerage system after treatment to conform to effluent standards. Hence, there will be no direct effluent discharges from electroplating plants into rivers. However, it should be considered that the untreated effluents from electroplating plants located in the Tokyo area may have been discharged directly into rivers during the time when pollution control was not sufficiently established yet.

In this study, we did not measure the $\delta^{66} \mathrm{Zn}$ values of untreated effluent samples from electroplating plants in the Tokyo area, because it was difficult to obtain such samples. Thus, available $\delta^{66} \mathrm{Zn}$ data for untreated effluent samples from electroplating plants are limited; however, Kurata et al. (2011) reported relatively high $\delta^{66} \mathrm{Zn}$ values of $+2.56 \%$ and $+0.28 \%$ for samples collected from two plants in the Tokyo area, in which the difference is probably caused by the $\delta^{66} \mathrm{Zn}$ of $\mathrm{Zn}$ ores as raw materials. Moreover, Kurata et al. (2011) showed that the $\delta^{66} \mathrm{Zn}$ of treated effluents decreases owing to isotopic fractionation during coagulation processes of effluents. John et al. (2007) found that electroplated $\mathrm{Zn}$ metal is isotopically lighter than common $\mathrm{Zn}$ metal, which is consistent with previous experimental results showing that there is a negative isotopic effect on $\mathrm{Zn}$ electroplating. Conversely, this finding suggests that $\mathrm{Zn}$ in the effluents from electroplating operations is isotopically heavier and consequently has higher $\delta^{66} \mathrm{Zn}$ values (John et al., 2007). Thus, $\mathrm{Zn}$ in the untreated effluents from electroplating plants may explain the high $\delta^{66} \mathrm{Zn}$ of anthropogenic $\mathrm{Zn}$ in the sediments from Tokyo Bay.

If this is the case, it is assumed that the untreated effluents from electroplating plants located in the Tokyo area were discharged directly into rivers before the 1970s when pollution control was not sufficiently established, and contributed significantly to Zn pollution in Tokyo Bay. On the basis of the measurement of Zn concentration in river bottom sediments (dredged samples collected around 2000) in the Tokyo area (Figure 7), the bottom sediments from the three 


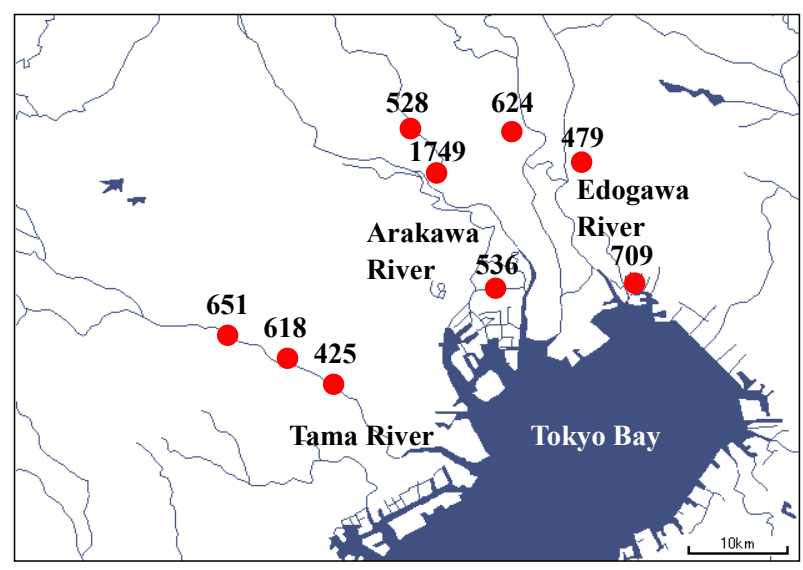

Figure 7. Zn concentration in river bottom sediments in Tokyo area (Geological Survey of Japan; https://gbank.gsj.jp/geochemmap/kanto/kantoshosai.htm).

principal rivers in urban sites have high $\mathrm{Zn}$ concentrations, exceeding the concentration $\left(400 \mu \mathrm{g} \cdot \mathrm{g}^{-1}\right)$ in surface sediments from Tokyo Bay. As mentioned in Section 3.2, it is likely that the $\mathrm{Zn}$ concentration in the three principal rivers increases with increasing amount of lithogenic particles (Figure 4), and $\mathrm{Zn}$ associated with those particles has relatively high $\delta^{66} \mathrm{Zn}$ (probably $>+0.4 \%$ ). In this study, the $\mathrm{Zn}$ concentration and $\delta^{66} \mathrm{Zn}$ in the rivers were measured primarily in ordinary runoff with low flow rates. In contrast, it is assumed that larger amounts of river bottom sediments are resuspended at higher flow rates during heavy rainfall, and discharged to the bay through river runoff. Thus, it is suggested that river bottom sediments contaminated with $\mathrm{Zn}$ are the principal sources of anthropogenic $\mathrm{Zn}$ with relatively high $\delta^{66} \mathrm{Zn}(+0.51 \%)$ in Tokyo Bay in the 1980s-2000s, during which time pollution control in industries and utilities was being established.

\section{Conclusion}

In this study, we evaluated the pollution sources of $\mathrm{Zn}$ in Tokyo Bay on the basis of $\delta^{66} \mathrm{Zn}$ in a sediment core. The results presented here support the hypothesis that the anthropogenic sources, which brought about the rapid increase in the Zn concentration in Tokyo Bay since about 1950, are the untreated effluents from electroplating plants located in the Tokyo area. Moreover, it is supposed that river bottom sediments, which were contaminated with $\mathrm{Zn}$ in the untreated effluents from electroplating plants in the past, are the principal sources of anthropogenic $\mathrm{Zn}$ in Tokyo Bay in the 1980s-2000s, during which time, pollution control in industries and utilities was being established. This suggests that the present pollution level of $\mathrm{Zn}$ has been maintained in Tokyo Bay over a long time, which may be a reason why the $\mathrm{Zn}$ concentration in the surface layer (2001-2003) of the core is still significantly higher than the background concentration. A similar result showing that contaminated river bottom sediments are the principal pollution sources in Tokyo Bay has been obtained for $\mathrm{Pb}$ pollution (Sakata et al., 2018). Thus, dredging channels may be an effective countermea- 
sure for reducing the loads of toxic substances such as heavy metals in Tokyo Bay.

\section{Acknowledgements}

The sediment core was collected by the Central Research Institute of Electric Power Industry (CRIEPI) where M.S. was a research scientist. We thank CRIEPI for providing the sediment core samples. This study was supported by the Japan Society for the Promotion of Science (Grant-in-Aid for Scientific Research No. 16K00622).

\section{Conflicts of Interest}

The authors declare no conflicts of interest regarding the publication of this paper.

\section{References}

Borrok, D. M., Wanty, R. B., Ridley, W. I., Wolf, R., Lamothe, P. J., \& Adams, M. (2007). Separation of Copper, Iron, and Zinc from Complex Aqueous Solutions for Isotopic Measurement. Chemical Geology, 242, 400-414. https://doi.org/10.1016/j.chemgeo.2007.04.004

Brown, J. N., \& Peake, B. M. (2005). Sources of Heavy Metals and Polycyclic Aromatic Hydrocarbons in Urban Stormwater Runoff. Science of the Total Environment, 359, 145-155. https://doi.org/10.1016/j.scitotenv.2005.05.016

Canavan, R. W., Van Cappellen, P., Zwolsman, J. J. G., van den Berg, G. A., \& Slomp, C. P. (2007). Geochemistry of Trace Metals in a Fresh Water Sediment: Field Results and Diagenetic Modeling. Science of the Total Environment, 381, 263-279. https://doi.org/10.1016/j.scitotenv.2007.04.001

Characklis, W. G., \& Wiesner, M. R. (1997). Particle, Metals and Water Quality in Runoff from Large Urban Watershed. Journal of Environmental Engineering, 123, 753-759. https://doi.org/10.1061/(ASCE)0733-9372(1997)123:8(753)

Chen, J., Gaillardet, J., \& Louvat, P. (2008). Zinc Isotopes in the Seine River Waters, France: A Probe of Anthropogenic Contamination. Environmental Science \& Technology, 42, 6494-6501. https://doi.org/10.1021/es800725z

Eckley, C. S., \& Branfireum, B. (2008). Mercury Mobilization in Urban Stormwater Runoff. Science of the Total Environment, 403, 164-177. https://doi.org/10.1016/j.scitotenv.2008.05.021

Fox, W. M., Johnson, M. S., Jones, S. R., Leah, R. T., \& Copplestone, D. (1999). The Use of Sediment Cores from Stable and Developing Salt Marshes to Reconstruct Historical Contamination Profiles in the Mersey Estuary, UK. Marine Environmental Research, 47, 311-329. https://doi.org/10.1016/S0141-1136(98)00123-8

Heim, S., Schwarzbauer, J., Kronimus, A., Littke, R., Woda, C., \& Mangini, A. (2004). Geochronology of Anthropogenic Pollutants in Riparian Wetland Sediments of the Lippe River (Germany). Organic Geochemistry, 35, 1409-1425. https://doi.org/10.1016/S0146-6380(04)00121-4

Hirao, Y., Mabuchi, E., Fukuda, E., Tanaka, H., Imamura, T., Todoroki, H., Kimura, K., \& Matsumoto, E. (1986). Lead Isotope Ratios in Tokyo Bay Sediments and Their Implications in the Lead Consumption of Japanese Industries. Geochemical Journal, 20, 1-15. 
https://doi.org/10.2343/geochemj.20.1

Hornberger, M. I., Luoma, S. N., van Geen, A., Fuller, C., \& Anima, R. (1999). Historical Trends of Metals in the Sediments of San Francisco Bay, California. Marine Chemistry, 64, 39-55. https://doi.org/10.1016/S0304-4203(98)80083-2

Hosono, T., Su, C.-C., Okamura, K., \& Taniguchi, M. (2010). Historical Record of Heavy Metal Pollution Deduced by Lead Isotope Ratios in Core Sediments from Osaka Bay. Journal of Geochemical Exploration, 107, 1-8. https://doi.org/10.1016/j.gexplo.2010.05.003

John, S. G., Park, J. G., Zhang, Z., \& Boyle, E. A. (2007). The Isotopic Composition of Some Common Forms of Anthropogenic Zinc. Chemical Geology, 245, 61-69. https://doi.org/10.1016/j.chemgeo.2007.07.024

Kang, J.-H., Lee, Y. S., Ki, S. J., Lee, Y. G., \& Cha, S. M. (2009). Characteristics of Wet and Dry Weather Heavy Metal Discharges in the Yeongsan Watershed, Korea. Science of the Total Environment, 407, 3482-3493. https://doi.org/10.1016/j.scitotenv.2009.02.021

Kitano, Y., Sakata, M., \& Matsumoto, E. (1980). Partitioning of Heavy Metals into Mineral and Organic Fractions in a Sediment Core from Tokyo Bay. Geochimica Cosmochimica Acta, 44, 1279-1285. https://doi.org/10.1016/0016-7037(80)90088-5

Kurata, K., Masunaga, S., Tanimizu, M., \& Naito, W. (2011). Analysis of Zinc Isotope Ratio in Environmental Water. In 20th Symposium on Environmental Chemistry Programs and Short Abstracts, Japan Society for Environmental Chemistry (pp. 844-845). Tsukuba: Japan Society for Environmental Chemistry. (In Japanese)

Mahler, B. J., Van Metre, P. C., \& Callender, E. (2006). Trends in Metals in Urban and Reference Lake Sediments across the United States, 1970 to 2001. Environmental Toxicology \& Chemistry, 25, 1698-1709. https://doi.org/10.1897/05-459R.1

Moeller, K., Schoenberg, R., Pedersen, R.-B., Weiss, D., \& Dong, S. (2012). Calibration of the New Certified Reference Materials ERM-AE633 and ERM-AE647 for Copper and IRMM-3702 for Zinc Isotope Amount Ratio Determinations. Geostandards and Geoanalytical Research, 36, 177-199. https://doi.org/10.1111/j.1751-908X.2011.00153.x

Ohno, T., Shinohara, A., Chiba, M., \& Hirata, T. (2005). Precise Zn Isotopic Ratio Measurements of Human Red Blood Cell and Hair Samples by Multiple Collector-ICP-Mass Spectrometry. Analytical Science, 21, 425-428.

https://doi.org/10.2116/analsci.21.425

Pearson, R. F., Swackhamer, D. L., Eisenreich, S. J., \& Long, D. T. (1997). Concentrations, Accumulations, and Inventories of Polychlorinated Dibenzo-p-Dioxins and Dibenzofurans in Sediments of the Great Lakes. Environmental Science \& Technology, 31, 2903-2909. https://doi.org/10.1021/es9701016

Sakata, M. (1985). Diagenetic Remobilization of Manganese, Iron, Copper and Lead in Anoxic Sediment of a Freshwater Pond. Water Research, 19, 1033-1038. https://doi.org/10.1016/0043-1354(85)90373-2

Sakata, M., Marumoto, K., Narukawa, M., \& Asakura, K. (2006). Mass Balance and Sources of Mercury in Tokyo Bay. Journal of Oceanography, 62, 767-775. https://doi.org/10.1007/s10872-006-0096-9

Sakata, M., Tani, Y., \& Takagi, T. (2008). Wet and Dry Deposition Fluxes of Trace Elements in Tokyo Bay. Atmospheric Environment, 42, 5913-5922. https://doi.org/10.1016/j.atmosenv.2008.03.027

Sakata, M., Takagi, T., \& Mitsunobu, S. (2010). Evaluation of Loads and Sources of Heavy Metals in Tama River, Tokyo. Water Air, \& Soil Pollution, 213, 363-373.

https://doi.org/10.1007/s11270-010-0391-3 
Sakata, M., Xu, H., \& Mashio, A. S. (2018). Analysis of Historical Trend of Pollution Sources of Lead in Tokyo Bay Based on Lead Isotope Ratios in Sediment Core. Journal of Oceanography, 74, 187-196. https://doi.org/10.1007/s10872-017-0448-7

Sansalone, J. J., \& Buchberger, S. G. (1997). Partitioning and First Flush of Metals in Urban Roadway Storm Water. Journal of Environmental Engineering, 123, 134-143. https://doi.org/10.1061/(ASCE)0733-9372(1997)123:2(134)

Terashima, S., Imai, N., Tachibana, Y., Okai, T., Mikoshiba, M., Ohta, A., \& Kubota, R. (2007). Chemical Composition and Background Evaluation of Soils and Stream Sediments from Kanto District, and Marine Sediments from Tokyo Bay. Bulletin of Geological Survey of Japan, 58, 69-91. (In Japanese) https://doi.org/10.9795/bullgsj.58.61

Thapalia, A., Borrok, D. M., Van Metre, P. C., Musgrove, M., \& Landa, E. R. (2010). Zn and $\mathrm{Cu}$ Isotopes as Tracers of Anthropogenic Contamination in a Sediment Core from an Urban Lake. Environmental Science \& Technology, 44, 1544-1550.

https://doi.org/10.1021/es902933y

Thapalia, A., Borrok, D. M., Van Metre, P. C., \& Wilson, J. (2015). Zinc Isotopic Signatures in Eight Lake Sediment Cores from across the United States. Environmental Science \& Technology, 49, 132-140. https://doi.org/10.1021/es5036893

Tang, W., Shan, B., Zhang, H., Zhang, W., Zhao, Y., Ding, Y., Rong, N., \& Zhu, X. (2014). Heavy Metal Contamination in the Surface Sediments of Representative Limnetic Ecosystems in Eastern China. Science Report, 4, Article No. 7152. https://doi.org/10.1038/srep07152

Togashi, S., Imai, N., Okuyama-Kusunose, Y., Tanaka, T., Okai, T., Koma, T., \& Murata, Y. (2000). Young Upper Crustal Chemical Composition of the Orogenic Japan Arc. Geochemistry, Geophysics, Geosystems, 1. https://doi.org/10.1029/2000GC000083

Westerlund, C., \& Viklander, M. (2006). Particles and Associated Metals in Road Runoff during Snow Melt and Rainfall. Science of the Total Environment, 362, 143-156. https://doi.org/10.1016/j.scitotenv.2005.06.031

Yasuhara, M., \& Yamazaki, H. (2005). The Impact of 150 Years of Anthropogenic Pollution on the Shallow Marine Ostracode Fauna, Osaka Bay, Japan. Marine Micropalaeontology, 55, 63-74. https://doi.org/10.1016/j.marmicro.2005.02.005 